\title{
Effect of biological colonization on ceramic roofing tiles by lichens and a combined laser and biocide procedure for its removal
}

J. Pena-Poza ${ }^{1}$, C. Ascaso ${ }^{2+}$, M. Sanz ${ }^{3}$, S. Pérez-Ortega ${ }^{4}$, M. Oujja $^{3}$, J. Wierzchos ${ }^{2}$, V. SouzaEgipsy $^{5}$, M.V. Cañamares ${ }^{5}$, M. Urizal ${ }^{6}$, M. Castillejo ${ }^{3}$, M. García-Heras ${ }^{1 *}$

${ }^{1}$ Instituto de Historia (CCHS-CSIC). Calle Albasanz 26-28. 28037 Madrid, Spain.

2 Museo Nacional de Ciencias Naturales (MNCN-CSIC). Calle Serrano 115bis. 28006 Madrid, Spain.

${ }^{3}$ Instituto de Química Física Rocasolano (IQFR-CSIC). Calle Serrano 119. 28006 Madrid, Spain.

${ }^{4}$ Real Jardín Botánico ((RJB-CSIC). Plaza Murillo 2. 28014 Madrid, Spain.

${ }^{5}$ Instituto de Estructura de la Materia (IEM-CSIC). Calle Serrano 121. 28006 Madrid, Spain.

${ }^{6}$ Thor Especialidades SA. Barcelona, Spain.

\section{${ }^{*}$ Corresponding author 1:}

Instituto de Historia, CCHS-CSIC. Calle Albasanz 26-28. 28037 Madrid, Spain.

Tel. +3491602 2465

Fax +3491602 2971

E-mail address: manuel.gheras@cchs.csic.es

\section{${ }^{+}$Corresponding author 2:}

Museo Nacional de Ciencias Naturales, MNCN-CSIC. Calle Serrano, 115bis. 28006 Madrid, Spain.

Tel. +3491745 2500 (Ext. 981010)

Fax +34 915645078

E-mail address: ascaso@mncn.csic.es

\section{Highlights}

- Removal of lichens on unglazed ceramic roofing tiles is studied.

- The lichens Verrucaria nigrescens, Calogaya decipiens and Pyrenodesmia teicholyta show differential substrate interaction related with its composition.

- A combined procedure based on dual sequential laser irradiation and biocide is tested.

- The procedure applied partially removes some lichen species and completely damages lichen bionts in all species. 


\begin{abstract}
Biodeterioration damage is an important issue in conservation and restoration of built heritage, especially when ceramic materials are used. Biological colonization of ceramic roofing tiles by lichens is a common phenomenon. However, there are no reports to date of lichens removal from unglazed roofing tiles for conservation purposes. This paper for the first time reveals the results of a combined procedure undertaken to assess the removal of lichens on different kinds of unglazed ceramic roofing tiles by treatments based on both dual sequential laser irradiation and treatment using Acticide ${ }^{\circledR}$ CF biocide. Three species of lichens were identified: Verrucaria nigrescens, Calogaya decipiens and Pyrenodesmia teicholyta. The chemical and mineralogical composition of roofing tiles were characterized by X-ray fluorescence (XRF) spectrometry, optical polarized petrographic microscopy, and X-ray diffraction (XRD). Laser irradiation was accomplished by applying sequences of nanosecond laser pulses at two wavelengths (1064 and $266 \mathrm{~nm}$ ). After dual sequential laser irradiation a biocide was applied. To assess the combined effect of both treatments several techniques were used, including stereo and fluorescence (FM) microscopies, scanning (SEM) and transmission (TEM) electron microscopies, and FT-Raman spectroscopy. Chemical composition of the analyzed roofing tiles was shown as a relevant factor regarding the degree of interaction between the biological colonization and the substrate, and hence, the bioweathering effect. The combined procedure has proved to be very effective in removing some lichen thalli and damaging completely the bionts in all species.
\end{abstract}

\author{
Keywords: \\ Biodeterioration \\ Ceramic roofing tiles \\ Lichens \\ Removal procedures \\ Laser irradiation \\ Biocide Acticide ${ }^{\circledR} \mathrm{CF}$
}




\section{Introduction}

A wide biodiversity has been recognized in architectural ceramic materials such as bricks, roofing tiles and glazed wall tiles. This biodiversity very often causes biodeterioration on these materials which in turn induce not only aesthetic but also chemical and physical damage. Decay by biodeterioration is an important issue in conservation and restoration of built heritage, especially when ceramic materials were used (Warren, 1999).

Different types of biological colonization have been identified in such materials, from microorganisms to plants, including bacteria, cyanobacteria, algae, lichens and fungi (Coutinho et al., 2015). Regarding biodeterioration damage, bricks are the most studied type of architectural ceramic material (Wang et al., 2011), while roofing (Gazulla et al., 2011) and glazed wall tiles (Coutinho et al., 2013) are hardly investigated. In addition, biodeterioration of stained glass windows have been also reported (Carmona et al., 2006). Studies focused on the impact of the lichen thalli on a monumental stone substrate have revealed a high bioreceptivity of rocks to lichen colonization depending on rock surface roughness, porosity, and capillarity, as well as a strong incidence of lichens in the biodeterioration of stone built heritage (de los Ríos et al., 2004, 2009).

Ceramic roofing tiles have been traditionally elaborated from a composition very similar to that used for bricks, that is, an uncoated or unglazed body mainly composed of illitic-kaolinitic clays with quartz and a variable amount of carbonates which is subsequently fired at low/medium temperatures. The main function of roofing tiles is to protect the building against rain and sun and, due to this reason they are commonly exposed to weathering and biological agents which later may cause biodeterioration. Fired clay roofing tiles were first used in Egypt and other ancient civilizations such as Babylon. However, Romans were probably the ancient people which more extensively roofed their buildings. Although the technique of glazed roofing tiles was already known by Babylonians it was widely spread later by the Islamic influence in medieval times (Campbell and Pryce, 2003).

Biological colonization of ceramic roofing tiles by lichens is a frequent and common phenomenon. However, this kind of colonization over the ceramic roofing tiles has been scarcely described (Kiurski et al., 2005). It affects not only the aesthetic aspects of the building roofs but also roof functionality can be affected by lichens cover (Laiz et al., 2006). For this reason any study related to the removal of lichens from roofing tiles may be of significant importance, even for roofing tiles conservation purposes. Removal procedures of biofilms composed by algae, cyanobacteria and fungi with application of four biocides have been evaluated, but in glazed majolica tiles, by Coutinho et al. (2016). However, the process of lichens eradication from ceramic roofing tiles has never been reported up to date.

In this study it is hypothesized that biological weathering (lichen thalli) of ceramic roofing tiles made by traditional methods of elaboration depends on the characteristics of the substrate (uncoated or unglazed ceramic). The usefulness of combined treatments using dual sequential laser irradiation and biocides is further assessed in order to help decision making in conservation and restoration of historical buildings in which ancient or traditional ceramic roofing tiles need to be necessarily preserved.

Laser cleaning is a well-established technique because it provides fine and selective removal of superficial deposits and encrustations such as biological and black crusts on stone substrates (Cooper, 1998; Maravelaki-Kalaitzaki et al., 2003; Tornari et al., 2006). In the case of lichen elimination, laser cleaning constitutes a promising alternative to more conventional cleaning techniques (de Cruz et al., 2009, Speranza et al., 2013, Osticioli et al., 2015). This technique has been also used for the elimination of dark deposits originated from air pollution on terracotta substrates, with close composition to ceramic roofing tiles (Oujja et al., 2005). 


\section{Materials and methods}

\subsection{Ceramic roofing tile samples}

Three unglazed ceramic roofing tiles coming from Segovia (samples 1 and 2) and Guadalajara (sample 3) provinces located in the center of Spain under a mesothermal climate were selected to undertake this research. All of them belonged to traditional rural built heritage and were elaborated following traditional methods. They have been naturally exposed to both weathering and biological agents for years and all showed an extensive biological colonization on their surfaces (Fig. 1).

Ceramic body samples from roofing tiles were characterized by the following techniques: $X$ ray fluorescence (XRF) spectrometry, optical polarized petrographic microscopy through thinsection examination, and $\mathrm{X}$-ray diffraction (XRD).

Chemical analyses by XRF were carried out with a PANalytical Axios wavelength dispersed X-ray spectrometer equipped with a rhodium tube of $4 \mathrm{~kW}$ and $60 \mathrm{kV}$. Analytical determinations were undertaken through the standard-less analytical software IQ+ (PANalytical) from synthetic oxides and natural minerals. Thin-sections for petrographic observations were cut perpendicularly to the surface of the roofing tiles. The observations were accomplished with a Kyowa Bio-Pol 2 polarizing light microscope. Micrographs from thin-sections were recorded with a Moticam 2500 camera. XRD analyses were carried out with a PANalytical X'Pert-MPD unit using Ka of copper radiation (1.54056 $\AA$ ), under set conditions of $45 \mathrm{kV}$ and $40 \mathrm{~mA}$. Diffractograms were obtained between $2 \theta=5-60^{\circ}$. Both XRD and XRF analyses were carried out on powder samples prepared by grinding ceramic body roofing tile fragments, with their most external surfaces removed to avoid contaminations by biocolonization, in an agate mortar.

\subsection{Procedures for the removal of the lichen thalli}

Lichen thalli were treated according to two different procedures: dual sequential laser irradiation alone and dual sequential laser irradiation plus chemical treatment containing an Acticide $^{\circledR}$ CF biocide. The most effective of the two procedures was the second one. Consequently, the results and discussion of this paper will be focused on this combined procedure. However, as control, untreated and only chemically treated thalli were also tested.

Regarding the best laser treatment to remove lichen thalli, some authors have reported dual IR-UV sequential irradiation at 1064 and $355 / 266 \mathrm{~nm}$ as the ideal treatment to eliminate lichen colonization crusts while ensuring preservation of the lithic substrate (Sanz et al., 2015, 2017). In the present study, dual IR-UV sequential irradiation at 1064 and $266 \mathrm{~nm}$ has been applied. The wavelength of $1064 \mathrm{~nm}$ was selected because it is known that it produces ultrastructural changes and therefore metabolic damage in the mycobiont hyphae penetrating stone substrates (Speranza et al., 2013), whereas the $266 \mathrm{~nm}$ wavelength is adequate because lichen specimens usually present larger light absorbance at this wavelength (Nguyen et al., 2013, Sanz et al., 2017). Dual sequential irradiation was carried out with a Qswitched Nd:YAG laser (pulse width $17 \mathrm{~ns}$, repetition frequency $1 \mathrm{~Hz}$ ) using the fundamental wavelength of $1064 \mathrm{~nm}$ and its fourth harmonic at $266 \mathrm{~nm}$. 
Sequences of 50 IR pulses followed by 50 UV pulses under the same irradiation path were applied in each treated area. The unfocussed laser beams, with a squared cross section of ca. $0.25 \mathrm{~mm}^{2}$, were directed to the surface of the sample with the help of mirrors. The pulse energy was measured in front of the sample by a joulemeter (Gentec ED-200). The laser fluences used for irradiation of the samples were $1.8 \mathrm{~J} \mathrm{~cm}^{-2}$ for 1064 and $0.2 \mathrm{~J} \mathrm{~cm}^{-2}$ for 266 $\mathrm{nm}$, respectively. These values are just below the corresponding ablation thresholds of the bare roof tiles. During irradiation, the samples were translated perpendicularly to the laser propagation direction to obtain uniformly irradiated areas of up to $1 \mathrm{~cm}^{2}$.

The chemical treatment that includes the biocide Acticide ${ }^{\circledR}$ CF supplied by Thor Specialties S.A. is based on the following components: 1) a mixture of alkyldimethylbenzylammonium chloride and 1-octyl-2H-isothiazol-3-one (Acticide ${ }^{\circledR} \mathrm{CL} 1$ ), which works as cleaner and antifungal/antialgal agents, both compounds are miscible with water and stable over the $\mathrm{pH}$ range 4-10 and up to temperature of approximately $60^{\circ} \mathrm{C}$; 2) 2-octil-2H-isotiazol-3-ona and terbutryn (Acticide ${ }^{\circledR} \mathrm{CF}$ ), antifungal/antialgal agents which are sparingly soluble in water and soluble in most organic solvents and stable in presence of light over a pH range 2-10 and up to temperature of $100{ }^{\circ} \mathrm{C}$; and 3) an alkyl polymethysiloxane (organosilicon polymer, Advansi ${ }^{\circledR}$ PMR) which is a water-repellent resin for waterproofing. The use of water-repellent resin was in agreement with the biocides application procedure elaborated by the company Thor Specialties S.A.

A water-repellent resin is prepared by adding $1 \%$ of Acticide ${ }^{\circledR}$ CF to a mixture of $250 \mathrm{~g}$ Advansil ${ }^{\circledR}$ PMR plus $4750 \mathrm{~g}$ of white spirit. Acticide ${ }^{\circledR}$ CL1 was applied with a brush and let it dry for $24 \mathrm{~h}$. Then, the water-repellent resin containing Acticide ${ }^{\circledR} \mathrm{CF}$ was applied.

\subsection{Techniques used to assess the effect of the different treatments}

Several techniques were applied, including stereomicroscopy to describe morphological changes, fluorescence microscopy (FM) to observe the viability of lichen photobionts after the different treatments, scanning electron microscopy (SEM) to analyze surface change of lichens, scanning electron microscopy in backscattered mode (SEM-BSE) to study the effects of treatments inside the thalli, transmission electron microscopy (TEM) to observe cytological induced alterations, and FT-Raman spectroscopy to detect possible structural and chemical changes.

Lichen thalli were examined under a Leica S8APO dissecting stereomicroscope and macroscopic photographs were taken with a Leica EC3 image capture system. Thallus identity was achieved following Smith et al. (2009) and Clauzade and Roux (1985). The preparations were observed through a Zeiss Axiolmager D1 fluorescence microscope with Plan-Apochromat x63/1.40 oil immersion objective. A CCD Axiocam HRc Rev 2 Zeiss camera and Carl Zeiss AxioVision 4.7 software were used to capture and record bright field and fluorescence signals. Fragments of untreated (control) and irradiated lichen thalli were gently separated from the substrate surface using a sterile blade. Hand-made sections of the lichen thallus immersed in distilled water were deposited on glass slides and after covering them by cover glass were examined in bright field and by fluorescent microscopy using sets of filters: DAPI (Zeiss Filter Set 49; Ex/Em: 323-347/385-455 nm) and rhodamine (Zeiss Filter Set 20; Ex/Em: 540-552/567-647 nm).

The surface of ceramic roofing tile samples colonized by lichen thalli untreated (control) and treated with the two procedures described in 2.2 were examined after air drying at least for $24 \mathrm{~h}$ by SEM at low vacuum with $20 \mathrm{kV}$ acceleration potential using a FEI Inspect-S SEM equipment. Samples of the lichen thalli-roofing tile interface were prepared for SEM-BSE using the method developed by Wierzchos and Ascaso (1994). The roofing tile samples, cut to expose cross-sections of both the lichen thalli and roofing tile substrate, were fixed in 
glutaraldehyde $3.25 \%$ in phosphate buffer and osmium tetroxide $1 \%$ in the same buffer, dehydrated in an ethanol series and embedded in LRWhite resin. After polymerization at 60 ${ }^{\circ} \mathrm{C}$ for $48 \mathrm{~h}$, surfaces were fine-polished and carbon coated. The resulting cross-sections were examined through a FEI Inspect-S SEM equipment with a solid-state four-diode, BSE detector operated at 20-25 kV acceleration potentials.

Fragments of the untreated (control) and chemically treated lichen thalli with the two procedures described in 2.2 were processed according to the protocol described by de los Ríos and Ascaso (2002). Samples were fixed in glutaraldehyde $3.25 \%$ and osmium tetroxide $1 \%$, dehydrated in an ethanol series and embedded in Spurr's resin at $70{ }^{\circ} \mathrm{C}$ for $48 \mathrm{~h}$. Ultrathin-sections were cut with an ultramicrotome Reichert Ultracut E, stained with lead citrate and observed in a Leo EM 910 and JEOL JEM 1011 TEM equipments at acceleration potential of $80 \mathrm{kV}$.

A RFS 100/S-G Bruker spectrometer equipped with a cooled Ge detector was employed for FT-Raman spectroscopic measurements. The excitation source consists of a continuous $\mathrm{Nd}$ :YAG laser emitting at $1064 \mathrm{~nm}$. Controlled laser power outputs (20-50 mW) were applied to avoid damage of the samples during measurements. The light scattered from an area of $<0.01 \mathrm{~cm}^{2}$ was collected in backscattering $\left(180^{\circ}\right)$ geometry. Each data point resulted from the accumulation of 500 scans and the wavenumber resolution was $4 \mathrm{~cm}^{-1}$.

A CM-310 Metrotec spectrocolorimeter was used to measure the chromatic properties of the roofing tile samples and specifically the changes that could have been induced by laser irradiation. The observation area was circular and $1 \mathrm{~cm}$ in diameter. Five spectra were obtained in each zone and averaged to obtain one data point. The CIE-Lab color space was used to measure color shifts expressed in three variables, namely, $\Delta L^{*}$ (positive values indicate lighter and negative values darker hues), $\Delta a^{*}$ (positive values indicate shift to red and negative values shift to green), and $\Delta b^{*}$ (positive values indicate shift to yellow and negative values shift to blue). The values of $L^{*}, a^{*}$ and $b^{*}$ were measured on a chosen reference (cut edge of the roofing tile), on the non-treated bio-encrustation and on the laser irradiated test-areas. The difference of the measured coordinates to the coordinates of the chosen reference for each sample was then calculated (i.e. $\Delta L^{*}=L^{*}-L^{*}$ ref, etc.). The magnitude of the overall color change is given by:

$$
\Delta E^{*}=\left[\left(\Delta L^{*}\right)^{2}+\left(\Delta a^{*}\right)^{2}+\left(\Delta b^{\star}\right)^{2}\right]^{1 / 2}
$$

\section{Results}

\subsection{Characterization of ceramic roofing tiles}

Chemical composition of the three roofing tiles is shown in Table S1 (Supplementary material). Tile samples 1 and 2 are non calcareous ceramics $(\mathrm{CaO}<5.00$ wt \%) with a high content of alumina (20.06 to $23.80 \mathrm{wt} \%$ ). By contrast, tile sample 3 is a highly calcareous ceramic material (23.40 wt \%) with the half content of alumina in comparison with tile samples 1 and 2 . It has been made from a calcareous clay rich in dolomite since it presents a rather high content of $\mathrm{MgO}$ (14.10 wt \%) (Trindade et al., 2009). Sample 2 is the roofing tile with the highest iron oxide concentration $\left(9.40 \mathrm{wt} \%\right.$ of $\left.\mathrm{Fe}_{2} \mathrm{O}_{3}\right)$.

A summary of resulting characterization data is given in Table 1. Tile sample 1 shows a reddish and quite homogeneous medium porosity matrix with low birefringence and an initial vitrification state. According to XRD data, it was elaborated from an illitic-smectitic clay. The inclusions observed are composed of quartz, feldspars and opaque nodules of iron oxides 
with rounded and sub-rounded morphologies and, except bigger punctual ones, not higher than $500 \mu \mathrm{m}$ in size.

Tile sample 2 shows an intense reddish and quite homogeneous medium porosity matrix with high birefringence and no vitrification evidences. According to XRD data, it was elaborated from an illitic clay. The inclusions observed are composed of quartz, feldspars, and abundant needle-like crystals of mica, some times higher than $500 \mu \mathrm{m}$ in size. Some of the inclusions exhibit sub-angular morphologies which suggest the use of a poorly sorted clay material.

Tile sample 3 shows an ochre and poor homogenized medium-high porosity matrix with very low birefringence and an advanced vitrification state. The identification of a low reflection of mullite by XRD indicates that the starting clay material could be a kaolinitic clay since mullite originates when kaolinite is fired at temperatures higher than $950-1000{ }^{\circ} \mathrm{C}$ (Maggetti, 1982). Except for a big argillaceous pellet of more than $1 \mathrm{~cm}$ in size, the scarce inclusions observed are composed of quartz and opaque iron nodules not larger than $200 \mu \mathrm{m}$ in size with rounded morphologies.

From the presence of neo-formed phases by XRD the approximate firing temperature has been estimated (Table 1). Tile sample 2 is the one fired at the lowest temperature since hematite is the only neo-formed phase identified. Due to the presence of still high reflections of illite and crystallization of hematite from $700{ }^{\circ} \mathrm{C}$ in oxidizing conditions (Nodari et al., 2007), a firing temperature of approximately $750-800{ }^{\circ} \mathrm{C}$ is estimated. Tile sample 2 is the one fired at an intermediate temperature due to the presence of neo-formed phases such as hematite, gehlenite, and diopside. Taking into account low reflections of both illite and smectite, crystallization of hematite, and formation of gehlenite and diopside from $850{ }^{\circ} \mathrm{C}$ (Peters and Iberg, 1978; Cultrone et al., 2001), a firing temperature of approximately 850-900 ${ }^{\circ} \mathrm{C}$ is estimated. Finally, tile sample 3 is the one fired at the highest temperature, which is estimated between 950 and $1000{ }^{\circ} \mathrm{C}$ due to the presence of anorthite, diopside, gehlenite, and mullite. Except mullite, the other three are typical high temperature phase reactions of carbonate-rich clays (Cultrone et al., 2001; Trindade et al., 2009). Therefore, the best sintered ceramic material is tile sample 3 while the poorest one is tile sample 2 . Tile sample 1 is in the middle in terms of sintering state.

\subsection{Identification of lichen thalli}

The lichen-forming fungi Verrucaria nigrescens, Calogaya decipiens and Pyrenodesmia teicholyta were identified as the most abundant species colonizing the roofing tiles. The three species were equally abundant in tile sample 1 . The two former were the most abundant in tile sample 2 , whereas $P$. teicholyta and $C$. decipiens were equally abundant in tile sample 3 .

\subsection{Effect of the different treatments}

\subsubsection{Tile sample 1}

The typical habitus of $V$. nigrescens is shown in Figure 2a. Peripheral lobes of a $P$. teicholyta thallus are found in the left (P). Both $P$. teicholyta (Fig. 2b) and $V$. nigrescens (Figs. 2c, 2d) show very light interactions with the substrate (S), finding hyphae inside the substrate very rarely (arrows). Following dual sequential laser irradiation at 1064 and $266 \mathrm{~nm}$, both stereoscopic (Fig. 2e) and SEM images (Fig. 2f) show the elimination of most $V$. nigrescens areolae. The remaining areolae show a greenish coloration due to the ablation of the cortical layer (Fig. 2e). The effect of the treatment on P. teicholyta is not so evident (P, Fig. 2e). The cross-section of the interface between $V$. nigrescens and the ceramic substrate examined by SEM-BSE shows numerous zones where the lichen has become detached (Fig. 2g). Closer observation (Fig. 2h) shows remaining areolae- completely collapsed (white arrow) and 
colonization inside the substrate also affected by the treatment showing clear hyphal collapse (black arrow). Since the laser extracted the areolae of $V$. nigrescens as shown by stereoscopic and SEM-BSE, no chemical treatment could be applied due to the absence of thalli and consequently there are not images from TEM of the cytological aspects of the bionts.

\subsubsection{Tile sample 2}

A stereomicroscope image of a typical untreated thallus of $C$. decipiens is shown in Fig. $3 a$. Interaction of lichen thalli with the substrate $(S)$ is scarce and hyphal penetration is very rarely observed (Fig. 3b). Figure 3c reveals the effect of dual laser irradiation at 1064 and $266 \mathrm{~nm}$ on a thallus of $C$. decipiens under the stereomicroscope. Only few areolae were detached by this treatment (Figs. 3c, 3d). Some thallus areas (Fig. 3c, arrows) have lost the cortical layer due to the laser action exposing the algal layer (green color). SEM observation of the thallus surface also reveals the loss of the cortical layer in some areas. Figure $3 \mathrm{e}$ shows a SEM-BSE image of a cross-section of a treated thallus showing that although some areolae persist some have lost the cortical layer (white asterisk) and thallus is clearly internally damaged with serious injuries in algal and medulla layers (arrows). In this latter figure the thallus-substrate interface shows the penetration of the mycobiont into the ceramic substrate (black asterisk). The ultrastructure of the photobiont of the untreated thallus is shown in Figure 3f. It corresponds to the typical structure of the genus Trebouxia: a central chloroplast with pyrenoid (p) and dense lipid globules called pyrenoglobuli (arrows). However, following dual laser irradiation the structure of the chloroplast changes dramatically (Fig. $3 g$ ). Thylakoids and pyrenoids appear unstructured (white arrows), and pyrenoglobuli (black arrows) only appear in peripheral zones of the pyrenoid. The application of the chemical treatment alone causes a deep alteration of the protoplast, which is not separated yet from the cell wall. In some cells the pyrenoid zone is still recognizable (Fig. 3h).

When dual sequential laser irradiation was combined with chemical treatment the effects on C. decipiens were also assessed by TEM, since this is the only technique able of detecting changes at the cell level. Cell destruction in the photobiont was complete. This could be seen as the destruction of the chloroplast and separation of the cell wall from the plasmalemma (arrows), accompanied by intense plasmolysis and cell death (Fig. 3i, white asterisks).

\subsubsection{Tile sample 3}

Untreated thalli of $P$. teicholyta are shown in Figure 4a. A tighter relationship with the substrate is observable in this species compared to the previous samples as it is revealed in the SEM-BSE image by the high number of substrate fragments embedded in the lichen thallus (Fig 4b, black arrows). Dual laser irradiation at 1064 and $266 \mathrm{~nm}$ produced an almost completed removal of upper layers of the thallus, revealing the algal layer (Fig. 4c, green areas), even though no areolae was completely removed using this treatment. SEM examination of the lichen surface also revealed the damage produced by dual laser irradiation (Fig. 4d, white arrows). The effect of this dual laser irradiation on the areolae is shown more clearly in Figure 4e. Algal and cortical layers are ablated from parts of the thallus (white arrows). The damage produced by the lichen thallus to the calcium-rich substrate was evident across several thallus zones and detached layers were as thick as 100 to $150 \mu \mathrm{m}$ (black arrows). Moreover, the thallus of $P$. teicholyta featured calcium-bearing (possibly calcium oxalate) mineral, as demonstrated by energy dispersive X-ray (EDS) microanalysis (data not shown). The presence of calcium deposits within lichen thallus has not been detected in lichen thalli growing on tile samples 1 and 2 .

The typical appearance of photobiont cells in control thallus is shown in TEM micrographs of Figure 4f. Partial destruction of both the algal and the medulla layers of $P$. teicholyta thalli after dual laser irradiation at 1064 and $266 \mathrm{~nm}$ may be observed in Figure 4g. Large parts of the photobiont layer and medulla are ablated (asterisks). The application of chemical treatment alone causes a deep alteration of the protoplast, which is still not separated from 
the cell wall (Fig. 4h). When subjected to combined dual sequential laser irradiation/chemical treatment, the TEM images showed that the photobiont is significantly damaged, lacking completely its typical ultrastructural features (Fig. 4i, arrows).

Figure 5 shows lichen thalli of $P$. teicholyta untreated $(a-b)$ and treated $(c-d)$ with the combined laser and chemical treatment. Either bright field (Fig. 5a) or fluorescence (Fig. 5b) images of untreated lichen thalli reveal the abundant presence of green algae cells. After laser and chemical treatment, distinct degradation of algae cells, appeared as dark spots and few green algae, may be appreciated in the bright field image (Fig. 5c). Fluorescence image obtained from the same area (Fig. 5d) mostly shows blue autofluorescence signal.

\subsection{FT-Raman spectroscopy measurements}

FT-Raman spectroscopic measurements were undertaken on bare and non-irradiated areas of the ceramic substrate and on those areas where the dual sequential laser irradiation at 1064 and $266 \mathrm{~nm}$ induced partial or almost complete elimination of the biodeterioration film. The FT-Raman spectra bands obtained on roofing tile sample 3 colonized by $P$. teicholyta and $C$. decipiens lichen thalli are listed in Table S2 (Supplementary material), together with the corresponding assignments (Long, 1977; Edwards et al., 2003). The spectrum of the bare ceramic substrate acquired on the non biocolonized back side of the roofing tile displays characteristics bands of $\alpha$-quartz $\left(145,207,347,465\right.$, and $\left.1086 \mathrm{~cm}^{-1}\right)$ and calcite $(297$ and $1086 \mathrm{~cm}^{-1}$ ). These bands correspond to the main components of this roofing tile (Table S1).

The spectrum of a non-irradiated zone with colonization by $P$. teicholyta and $C$. decipiens lichen thalli presents some small features at $1082 \mathrm{~cm}^{-1}$ that may be attributed to $\mathrm{SiO}_{2}$ and $\mathrm{CO}_{3}$ stretching contribution of the roofing tile substrate (see Table S2, Edwards et al., 1992), as well as additional bands that are assigned to the lichen compounds, namely parietin (at 1160 and $1188 \mathrm{~cm}^{-1}$ ) and carotene (at 995, 1160 and $1524 \mathrm{~cm}^{-1}$ ), a compound produced by the lichen photobiont. Additionally, in the spectra of non-irradiated and irradiated areas of the tile sample, some other bands at 504, 899, 1464, 1490 and $1669 \mathrm{~cm}^{-1}$, could be attributed to calcium oxalate monohydrate (whewellite). The presence of this compound is probably due to the reaction between oxalic acid from the lichen and calcium from the substrate and thus is not present in the bare tile. The bands of the lichen compounds almost disappear after dual laser irradiation of the colonized surface, while the bands corresponding to the ceramic substrate weakly emerge in the spectrum, indicating lichen removal.

\subsection{Colorimetric measurements}

Table 2 displays the colorimetric coordinates of the three areas measured in each roofing tile sample. Tile sample 1 shows a moderate discoloration induced by dual sequential laser irradiation $\left(\Delta \mathrm{E}^{*}=16.9\right)$. The main color shift is due to changes in $\Delta \mathrm{a}^{*}(-12.3$, shift to greener $)$, $\Delta b^{*}\left(-8.8\right.$, shift to bluer) and $\Delta L^{*}(-7.6$, shift to a darker hue). Tile sample 2 shows a lower discoloration $\left(\Delta \mathrm{E}^{*}=15.3\right)$ than tile sample 1 . In this case, the main color shift is due to changes in $\Delta a^{*}\left(-12.3\right.$, shift to greener), $\Delta b^{*}\left(-7.9\right.$, shift to bluer) and $\Delta L^{*}$ (4.7, shift to a lighter hue). The overall color changes determined on tile sample $3\left(\Delta \mathrm{E}^{*}=16.1\right)$ is ascribed to slight shift to blue color and to the fact that the laser irradiated area of the tile becomes darker. Finally, after application of chemical treatment alone it was not possible to carry out colorimetric measurements of the substrate since the chemical treatment alone did not destroy the lichen thalli and, consequently, the underlying substrate was not visible. 


\section{Discussion}

Among the three ceramic roofing tiles examined in this research, tile sample 1, colonized by Pyrenodesmia teicholyta and Verrucaria nigrescens showed scarce signs of bioweathering of the ceramic material (Figs. 2b, 2c). This is in clear contrast with the results of a study which addressed the effects of $\mathrm{Nd}$ :YAG laser irradiation on quarry dolostone colonized by $V$. nigrescens. In this study it was observed that this species did intensely alter the stone substrate (Speranza et al., 2013). The discrepancy could be attributed to the chemical composition of tile sample 1, a non-calcareous alumina-rich ceramic (Table S1, $4.50 \mathrm{wt} \%$ of $\mathrm{CaO}$ and 20.06 wt $\%$ of $\mathrm{Al}_{2} \mathrm{O}_{3}$ concentrations) made from an illitic-smectitic clay. C. decipiens colonizing the non-calcareous and also alumina-rich tile sample 2 showed as well little signs of bioweathering (Fig. 3b). All three species grow typically on calciferous substrates, often subjected to nitrogen deposition (Nimis, 2016). Their presence in tile samples 1 and 2 is evidently linked to the abundant nitrogen availability typical of rural environments in which roofing tiles were located.

However, tile sample 3 was remarkably penetrated by the thallus of $P$. teicholyta. In this case, besides fungal penetration into the substrate, it was possible to observe substrate fragments embedded within the lower medulla (Fig. 4b). Most likely, the highly calcareous nature of this substrate (Table $\mathrm{S} 1,23.40 \mathrm{wt} \%$ of $\mathrm{CaO}$ concentration) and its medium porosity produced by the release of $\mathrm{CO}_{2}$ in the decomposition of high amounts of carbonates, leads to the trapping of tile micro-fragments within the lichen thallus accompanied by micro-crystals of a calcium compound, possibly calcium oxalate, neoformed in the thallus (Figs. $4 b$ and $4 \mathrm{e}$ ). The presence of calcium oxalate in lichen thalli is known since 1982 (Ascaso et al., 1982) even in the lichens on rock substrates of Antarctica. In these rocks, whewellite (calcium oxalate dihydrate) and calcite have been observed in the contact area between the lichen and the rock (Ascaso et al., 1990). Calcium oxalate is also observed in the thalli of lichens colonizing granite. Recent irradiation of Protoparmeliopsis and Aspicilia colonizing rocks of a granite quarry has revealed the accumulation of surprisingly large amounts of calcium in their thalli (Sanz et al., 2017). This suggests that biomobilization of calcium occurs in higher extent in tile sample 3 than in tile sample 1. Such biomobilization processes have been well established (de los Ríos et al., 2004). However, so far it is not possible to establish the relevance of these calcium deposits for the laser treatment.

It is evident that the three ceramic roofing tiles show different patterns in terms of biodeterioration. These patterns seem to be related with chemical composition rather than the state of sintering reached by the ceramic material. Thus, non calcareous and aluminarich tile samples 1 and 2 barely showed signs of bioweathering in spite of both present medium porosity and even an initial vitrification sintering state in the case of tile sample 1 . On the contrary, the best sintered tile sample, the highly calcareous tile sample 3 , displayed a thallus penetration inside the ceramic substrate although it was fired near to $1000^{\circ} \mathrm{C}$ (Table 1). A higher bioweathering has been therefore observed in the roofing tile with the highest content of $\mathrm{CaO}$, whereas bioweathering of alumina-rich tile samples 1 and 2 seems to be very low.

In the present study based on sequential irradiation at 1064 and $266 \mathrm{~nm}$, it has been observed that effectiveness of the treatment depends on lichen species. Thus, many areolae were ablated from $V$. nigrescens thalli (Figs. $2 e, 2 f$ ), even though the effect on $C$. decipiens was not so pronounced macroscopically, with only some areolae detached (Fig. 3d). However, the laser treatment caused the total collapse of the lichen thallus, removing most of the cortical layer and exposing the photobiont cells (Fig. 3c). The treatment of $P$. teicholyta did not remove thallus areolae (Fig. 4c), although the cortical layer was ablated in most of the surface (Figs. 4c, 4d). SEM-BSE micrographs (Fig. 4e) show that elimination of upper thallus layers may reach a depth of around $150 \mu \mathrm{m}$. The collapse of remaining lichen thallus after laser irradiation is observable in TEM micrograph of Figure $4 \mathrm{~g}$, which reveals large gaps in 
the thallus structure, while dual sequential laser irradiation plus chemical treatment produce a complete damage (Fig. 4i) of both photobiont and mycobiont cells, thereby proving the lack of viability of the remaining lichen structures due to the chemical treatment (Fig. 4h) produces a synergic effect with the laser. Although laser treatment causes the collapse of all lichen species studied, differential effects on laser irradiation was observed. Differences related to lichen species identity have been recently showed, pointing out as potential causes of uneven effectiveness the contrasting thallus structure, the presence of distinct lichen substances and the presence of calcium oxalate (Sanz et al., 2017). On the other hand, the effect of either the laser or the combined treatment (laser + chemical treatment) does not seem to be affected by the chemical composition.

Fluorescence images also reveal the lack of viability after dual laser irradiation and chemical treatment (Fig. 5). Red autofluorescence signal of $P$. teicholyta thallus (Fig. 5b), which indicates a healthy status of photobiont cells, disappears after dual laser irradiation and chemical treatments, indicating loss of potential viability of the photobiont (Fig. 5d). This degradation of the algal cells is also evident on the bright field image characterized by the presence of dark brown spots (Fig. 5c). It is largely known that biocides affect lichen viability and that their effect depends on the way they are applied as well as on the target species (Favero-Longo et al. 2017). Moreover, the fluorescence image obtained from the same area (Fig. 5d) mostly shows blue autofluorescence coming from rests of dead algae cells. Thus, fluorescence imaging also indicates the destructive action on lichen thalli of the dual laser irradiation plus the chemical treatment. Accordingly, it can be stated that in response to the biocide $P$. teicholyta undergoes cell collapse and that following laser and biocide combined treatment, the structure of the thallus is disrupted and cell death occurs in the symbionts.

The naked appearance shown by a portion of the pyrenoid of $C$. decipiens photobiont (Fig. 3h) should be interpreted as a consequence of a dehydrating effect as previously discussed in dehydrated thalli (Brown et al., 1987). In this case, dehydration is due to the effect of the dual laser treatment. Weak staining of parts of its proteinaceous matrix indicates substantial damage to the pyrenoid and thus to the algal cell, since its photosynthetic capacity is disrupted through loss of the Rubisco enzyme. Likewise, the photobiont of $P$. teicholyta completely lost its typical cell organization as shown by analyses of its ultrastructure, being impossible to distinguish any eukaryotic cell organelle (Fig. 4i).

The measurements by FT-Raman spectroscopy provide with additional evidence of removal of the lichen thalli. In the spectra of the laser irradiated zone no new peaks appear after dual laser irradiation, thereby indicating the absence of chemical changes in the ceramic substrate that could be induced by laser removal of lichens. Light to moderate color changes were determined by colorimetric measurements on laser irradiated areas of the tile samples in comparison with the cut edge area which probably was not exactly the color of the original clean surface without biodeterioration. This is the most complex issues when discussing the optimum color of the cleaned surface, no matter the cleaning method used to characterize, identify or select the "reference" surface.

\section{Conclusions}

Bioweathering by lichen thalli of traditional made unglazed ceramic roofing tiles depends mainly on the chemical composition rather than the state of sintering of the ceramic substrate since calcium-rich tiles showed higher bioweathering than alumina-rich ones. A combined treatment based on dual sequential laser irradiation and chemical treatment has resulted to be usefulness for removal of lichen thalli. Laser irradiation first damages thallus structure, thereby opening paths to biocide penetration. The biocide seriously alters then the 
ultrastructure of the lichen symbionts (photobiont and mycobiont) and, consequently, induces the ablation of the lichen thallus in a short period of time. This treatment could be of great help in providing control of biodeterioration processes by lichens in conservation and restoration of unglazed ceramic roofing tiles of historical buildings.

\section{Acknowledgements}

This work was supported by research programs Geomateriales 2 (Ref. S2013/MIT-2914, Regional Government of Madrid and EU structural funds) and IPERION-CH (Integrated Platform for the European Research Infrastructure on Cultural Heritage, Ref. H2020INFRAIA-2014-2015 no 654028). Servicios de Microscopia from MNCN-CSIC and CNB-CSIC are gratefully acknowledged. SPO is supported by the grant RYC-2014-16784 and CA and JW by the grant CGL2013-42509P, both from the Spanish Ministry of Economy, Industry and Competitiveness. Finally, the authors are indebted to the TechnoHeritage network on Science and Technology for the Conservation of Cultural Heritage for its professional support.

\section{References}

Ascaso, C., Galván, J., Rodríguez-Pascual, C., 1982. The weathering of calcareous rocks by lichens. Pedobiologia 24, 219-229. http://doi:10.1007/BF00236519.

Ascaso, C., Sancho, L.G., Rodríguez-Pascual, C., 1990. The weathering action of saxicolous lichens in maritime Antarctica. Polar Biol. 11, 33-39. http://doi:10.1007/BF00236519.

Brown, D.H., Rapsch, S., Beckett, A., Ascaso, C., 1987. The effect of desiccation on cell shape in the lichen Parmelia sulcata. New Phytol. 105, 295-299. http://10.1111/j.14698137.1987.tb00867.x.

Campbell, J.W., Pryce, W., 2003. Brick: a world history. Thames \& Hudson, London.

Carmona, N., Laiz, L., González, J.M., García-Heras, M., Villegas, M.A., Saiz-Jiménez, C., 2006. Biodeterioration of historic stained glasses from the Cartuja de Miraflores (Spain). Int. Biodeterior. Biodegrad. 58, 155-161. http://10.1016/j.ibiod.2006.06.014.

Clauzade, G., Roux, C., 1985. Likenoj de okcidenta europo. Ilustrita determinlibro. Bull. Soc. Bot. C. Ouest. 7: 1-893.

Cooper, M., 1998. Laser Cleaning in Conservation: an Introduction. Butterworth Heinemann, Oxford.

Coutinho, M.L., Miller, A.Z., Gutiérrez-Patricio, S., Hernández-Marine, M., Gómez-Bolea, A., Rogerio-Candelera, M.A., Philips, A.J.L., Jurado, V., Saiz-Jiménez, C., Macedo, M.F., 2013. Microbial communities on deteriorated artistic tiles from Pena National Palace (Sintra, Portugal). Int. Biodeterior. Biodegrad. 84, 322-332. http://10.1016/j.ibiod.2012.05.028.

Coutinho, M.L., Miller, A.Z., Macedo, M.F., 2015. Biological colonization and biodeterioration of architectural ceramic materials: An overview. J. Cult. Herit. 16, 759-777. http://10.1016/j.culher.2015.01.006.

Coutinho, M.L., Miller, A.Z., Martín-Sánchez, P.M., Mirão, J., Gómez-Bolea, A., MachadoMoreira, B., Cerqueira-Alves, L., Jurado, V., Saiz-Jiménez, C., Lima, A., Phillips, A.J.L., Pina, F., Macedo, M.F., 2016. A multi-proxy approach to evaluate biocidal treatments on biodeteriorated majolica glazed tiles. Environ. Microbiol. http://doi:10.1111/14622920.13380.

Cultrone, G., Rodríguez-Navarro, C., Sebastián, E., Cazalla, O., De la Torre, M.J., 2001. Carbonate and silicate phase reactions during ceramic firing. Eur. J. Mineral. 13, 621-635. http://10.1127/0935-1221/2001/0013-0621. 
de Cruz, A., Wolbarsht, M.L., Andreotti, A., Colombini, M.P., Pinna, D., Culberson, C.F., 2009. Investigation of the Er:YAG laser at $2.94 \mathrm{~mm}$ to remove lichens growing on stone. Studies in Conservation 54, 268-277. http://10.1179/sic.2009.54.4.268.

de los Ríos, A., Ascaso, C., 2002. Preparative techniques for transmission electron microscopy and confocal laser scanning microscopy of lichens. In: Kranner, I., Beckett, R.P., Varma, A.K., (Eds.), Protocols in lichenology, Springer, Berlin, pp. 87-151.

de los Ríos, A., Galván, V., Ascaso, C., 2004. In situ microscopical diagnosis of biodeterioration processes occurring in the Convent of Santa Cruz la Real (Segovia, Spain). Int. Biodeterior. Biodegrad. 54, 113-120. http://10.1016/j.ibiod.2004.03.020.

de los Ríos, A., Cámara, B., García del Cura, M.A., Rico, V.J., Galván, V., Ascaso, C., 2009. Deteriorating effects of lichen and microbial colonization of carbonate building rocks in the Romanesque churches of Segovia (Spain). Sci. Total Environ. 407, 1123-1134. http://10.1016/j.scitotenv.2008.09.042.

Edwards, H.G.M., Farwell, D.W., Jenkins, R., Seaward, M.R.D., 1992. Vibrational Raman spectroscopic studies of calcium oxalate monohydrate and dihydrate in lichen encrustations on Renaissance frescoes. J. Raman Spectrosc. 23, 185-189. http:// 10.1002/jrs.1250230310.

Edwards, H.G.M., Newton, E.M., Wynn-Williams, D.D., Coombes, S.R., 2003. Molecular spectroscopic studies of lichen substances 1: parietin and emodin. J. Mol. Struct. 648, 4959.

Favero-Longo, S.E., Benesperi, R., Bertuzzi, S., Bianchi, E., Buffa, G., Giordani, P., Loppi, S., Malaspina, P., Matteucci, E., Paoli, L., Ravera, S., Roccardi, A., Segimiro, A., Vannini, A., 2017. Species-and site-specific efficacy of commercial biocides and application solvents against lichens. Int. Biodeterior. Biodegrad. 123, 127-137. http://10.1016/j.ibiod.2017.06.009.

Gazulla, M.F., Sánchez, E., González, J.M., Portillo, M.C., Orduna, M., 2011. Relationship between certain ceramic roofing tile characteristics and biodeterioration. J. Eur. Ceram. Soc. 31, 2753-2761. http://10.1016/j.jeurceramsoc.2011.07.023.

Kiurski, J.S., Ranogajec, J.G., Ujhelji, A.L., Radeka, M.M., Bokorov, M.T., 2005. Evaluation of the effect of lichens on ceramic roofing tiles by scanning electron microscopy and energy-dispersive spectroscopy analyses. Scanning 27, 113-119. http://10.1002/sca.4950270302.

Laiz, L.L., González, J.M., Saiz-Jiménez, C., Portillo, M.C., Gazulla, M.F., Sánchez, E., 2006. Microbial assessment of the biological colonization on roofing tiles. In: Fort, R., Álvarez de Buergo, M., Gómez-Heras, M., Vázquez-Calvo, C., (Eds.), Heritage, Weathering and Conservation, Vol. 1, Taylor \& Francis, London, pp. 349-353.

Long, D.A., 1977. Raman Spectroscopy. McGraw Hill Intl. Book Company, New York.

Maggetti, M., 1982. Phase analysis and its significance for technology and origin. In: Olin, J.S., Franklin, A.D., (Eds.), Archaeological Ceramics, Smithsonian Institution Press, Washington D.C., pp. 121-133.

Maravelaki-Kalaitzaki, P., Zafiropulos, V., Pouli, P., Anglos, D., Balas, C., Salimbeni, R., Siano, S., Pini, R., 2003. Short free running Nd:YAG laser to clean different encrustations on Pentelic marble: procedure and evaluation of the effects. J. Cult. Herit. 4, 77s-82s. http://10.1016/S1296-2074(02)01151-2.

Nimis, P.L., 2016. The Lichens of Italy. Edizioni Università di Trieste, Trieste.

Nguyen, K.-H., Chollet-Krugler, M., Gouault, N., Tomasi, S., 2013. UV-protectant metabolites from lichens and their symbiotic partners. Nat. Prod. Rep. 13, 1490-1508. http://10.1039/C3NP70064J.

Nodari, L., Marcuz, E., Maritan, L., Mazzoli, C., Russo, U., 2007. Hematite nucleation and growth in the firing of carbonate-rich clay for pottery production. J. Eur. Ceram. Soc. 27, 4665-4673. http://10.1016/j.jeurceramsoc.2007.03.031.

Osticioli, I., Mascalchi, M., Pinna, D., Siano, S., 2015. Removal of Verrucaria nigrescens from Carrara marble artefacts using Nd:YAG lasers: comparison among different pulse durations and wavelengths. Appl. Phys. A 118, 1517-1526. http://10.1007/s00339-0148933-y. 
Oujja, M., Rebollar, E., Castillejo, M., Domingo, C., Cirujano, C., Guerra-Librero, F., 2005. Laser cleaning of terracotta decorations of the portal of Palos of the Cathedral of Seville. J. Cult. Herit. 6, 321-327. http://10.1016/j.culher.2005.05.001.

Peters, T., lberg, R., 1978. Mineralogical changes during firing of calcium-rich brick clays. Am. Ceram. Soc. Bull. 57, 503-509.

Sanz, M., Oujja, M., Ascaso, C., de los Ríos, A., Pérez-Ortega, S., Souza-Egipsy, V., Wierzchos, J., Speranza, M., Cañamares, M.V., Castillejo, M., 2015. Infrared and ultraviolet laser removal of crustose lichens on dolomite Heritage stone. Appl. Surf. Sci. 346, 248-255. http://10.1016/j.apsusc.2015.04.013.

Sanz, M., Oujja, M., Ascaso, C., Pérez-Ortega, S., Souza-Egipsy, V., Fort, R., de los Ríos, A., Wierzchos, J., Cañamares, M.V., Castillejo, M., 2017. Influence of wavelength on the laser removal of lichens colonizing heritage stone. Appl. Surf. Sci. 399, 758-768. http://10.1016/j.apsusc.2016.12.032.

Smith, C.W., Aptroot, A., Coppins, B.J., Fletcher, A., Gilbert, O.L., James, P.W., Wolseley P.A., (Eds.) 2009. The Lichens of Great Britain and Ireland. The British Lichen Society, London.

Speranza, M., Sanz, M., Oujja, M., De los Rios, A., Wierzchos, J., Pérez-Ortega, S., Castillejo, M., Ascaso, C., 2013. ND-YAG laser irradiation damages to Verrucaria nigrescens. Int. Biodeterior. Biodegrad. 84, 281-290. http://10.1016/j.ibiod.2012.02.010.

Tornari, V., Fotakis, C., Georgiou, S., Zafiropulos, V., Anglos, D., 2006. Laser cleaning of encrustation. In: Fotakis, C., Anglos, D., Georgiou, S., Zafiropulos, V., Tornari, V. (Eds.), Laser in the Preservation of Cultural Heritage. Principles and Applications. Taylor \& Francis, London, pp. 336.

Trindade, M.J., Dias, M.I., Coroado, J., Rocha, F., 2009. Mineralogical transformations of calcareous rich clays with firing: A comparative study between calcite and dolomite rich clays from Algarve, Portugal. Appl. Clay Sci. 42, 345-355. http:// 10.1016/j.clay.2008.02.008.

Wang, Q., Ma, G.Y., He, L.Y., Sheng, X.F., 2011. Characterization of bacterial community inhabiting the surfaces of weathered bricks of Nanjing Ming city walls. Sci. Total Environ. 409, 756-762. http://10.1016/j.scitotenv.2010.11.001.

Warren, J., 1999. Conservation of Brick. Butterworth Heinemann, London.

Wierzchos, J., Ascaso, C., 1994. Application of back-scattered electron imaging to the study of the lichen-rock interface. J. Microsc. 175, 54-59. http://10.1111/j.13652818.1994.tb04787.x. 


\section{FIGURE CAPTIONS}

Figure 1. Ceramic roofing tiles studied. a) Tile sample 1. b) Tile sample 2. c) Tile sample 3.

Figure 2. Biological colonization of roofing tile sample 1 and its treatment. a) Untreated thallus of $V$. nigrescens (dark brown, $V$ ) and $P$. teicholyta (light grey, $P$ ). b) SEM-BSE micrograph showing a cross-section of $P$. teicholyta and its interaction with the substrate (S) (black arrows). c-d) SEM-BSE micrographs showing a cross-section of $V$. nigrescens and its interaction with the substrate (S) (black arrows). e) $V$. nigrescens and $P$. teicholyta $(\mathrm{P})$ thalli under the stereosmicroscope after dual laser irradiation (1064 and $266 \mathrm{~nm}$ ). Areas with high number of ablated areolae are indicated with black asterisks. f) SEM micrograph showing $V$. nigrescens and $P$. teicholyta $(P)$ thalli after dual laser irradiation. g) SEM-BSE micrograph showing a cross-section of $V$. nigrescens following dual laser irradiation. The elimination of many areolae (white arrows) may be noted. h) Higher magnification detail showing thallus collapse of the remaining areolae (white arrow) and collapse of colonization inside the substrate (black arrow).

Figure 3. Biological colonization (C. decipiens) of roofing tile sample 2 and its treatment. a) Typical habitus of an untreated healthy thallus. b) SEM-BSE micrograph showing a crosssection of a thallus. No interaction with the substrate (S) is observable. c) Stereomicroscope image following dual laser irradiation (1064 and $266 \mathrm{~nm}$ ). White and black arrows indicate areas of the thallus where the cortical layer was ablated. d) SEM-BSE micrograph showing a cross-section of a thallus after dual laser irradiation. White arrows indicate areas where areolae were removed. e) SEM-BSE micrograph of a thallus cross-section after laser treatment. White asterisks indicate affected cortical layers. White arrows point out collapsed medullar areas. Black asterisk point out slight penetration of the mycobiont inside the substrate. f) TEM micrograph of a healthy algal cell (photobiont) in an untreated $C$. decipiens thallus, showing pyrenoid ( $p$ ) and pyrenoglobuli (white arrows). g) Photobionts after dual laser irradiation. White arrows point out unstructured chloroplasts. Black arrows point out unstructured pyrenoids. h) Photobionts $(p)$ and mycobionts $(m)$ after chemical treatment with cell alteration without too many gaps between protoplast and cell wall. i) Photobiont cells after dual laser irradiation and chemical treatments. Black arrows point out to cytoplasm separation from the cell wall, while white asterisks indicate cell death.

Figure 4. Biological colonization ( $P$. teicholyta) of roofing tile sample 3 and its treatment. a) Typical habitus of an untreated healthy thallus under the stereomicroscope. b) SEM-BSE micrograph showing a cross-section of a thallus. Substrate (S) particles embedded in lichen thallus are pointed out by black arrows. c) Stereomicroscope image of a thallus after dual laser irradiation (1064 and $266 \mathrm{~nm}$ ). Green areas reveal loss of the cortical layer. d) SEM micrograph showing thallus surface after dual laser irradiation. White arrows indicate areas with cortical loss. f) SEM-BSE micrographs showing thallus cross-sections after dual laser irradiation treatment. White arrows point out areas where cortical and algal layers were ablated. Black arrows point out mycobiont-substrate interface with substrate fragments embedded in thallus. White asterisk indicates a calcium oxalate deposit. f) TEM micrograph of a healthy algal cell (photobiont) from an untreated thallus, pyrenoid (p). White arrows point out to pyrenoglobuli. g) TEM micrograph of thallus section gaps after dual laser irradiation treatment. Gaps in thallus structure are marked with black asterisks. h) Photobionts $(p)$ and mycobionts $(\mathrm{m})$ after chemical treatment with cell alteration and rather good adherence between plasmalem and cell wall. Asterisk indicate adhesion between plasmalem and cell wall. i) TEM micrograph of thallus section after dual laser irradiation and chemical treatments. Alteration of photobiont cells showing the lack of ultrastructure features and gaps between plasmalem and cell wall (black arrows).

Figure 5. Bright field (BF) and fluorescence microscopy (FM) images of sections of $P$. teicholyta thalli on roofing tile sample 3. a) BF image, untreated thallus. b) FM image, 
727 untreated. Red color comes from chloroplasts of potentially viable algae cells. c) BF image of 728 a thallus after dual laser irradiation and biocide treatments. d) FM image after dual laser 729 irradiation and biocide treatments. 


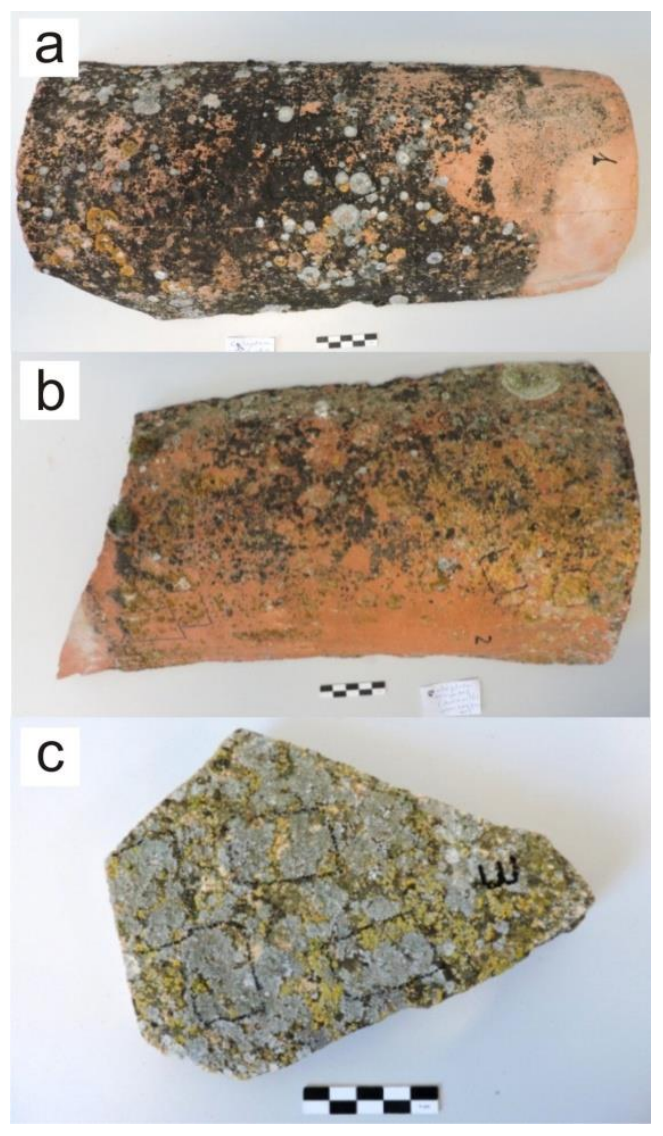

Figure 1 

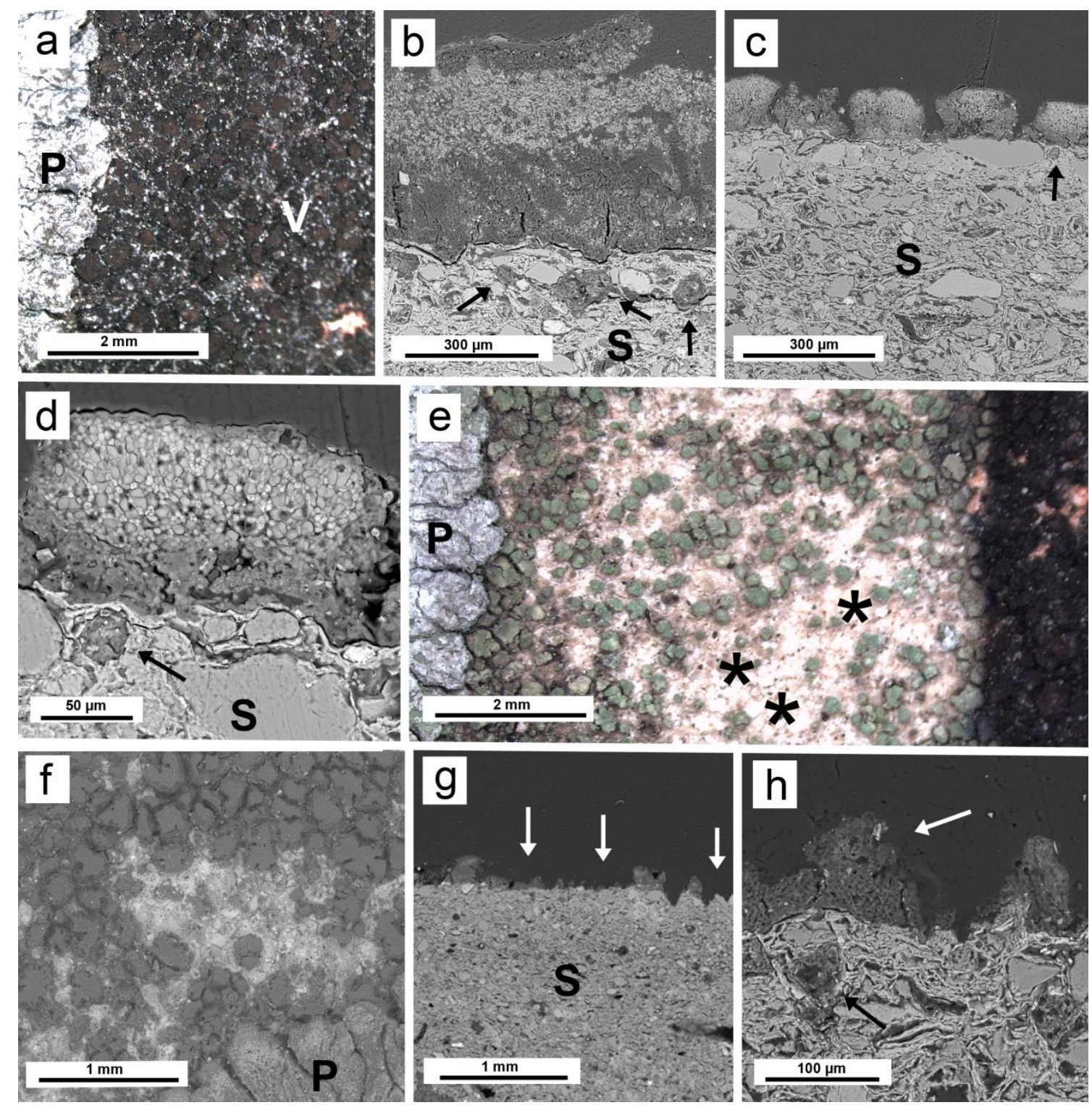

Figure 2 

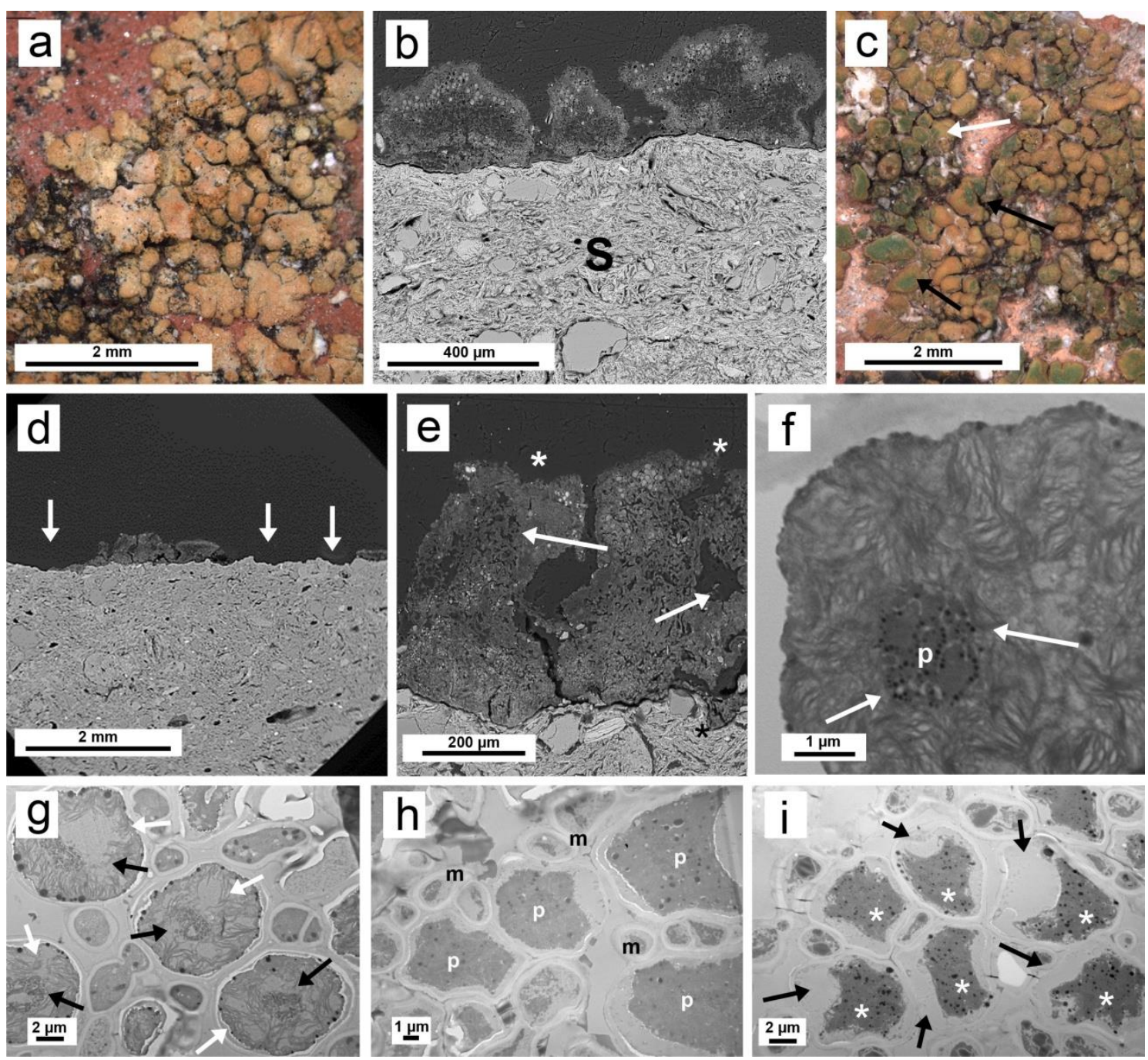

Figure 3 

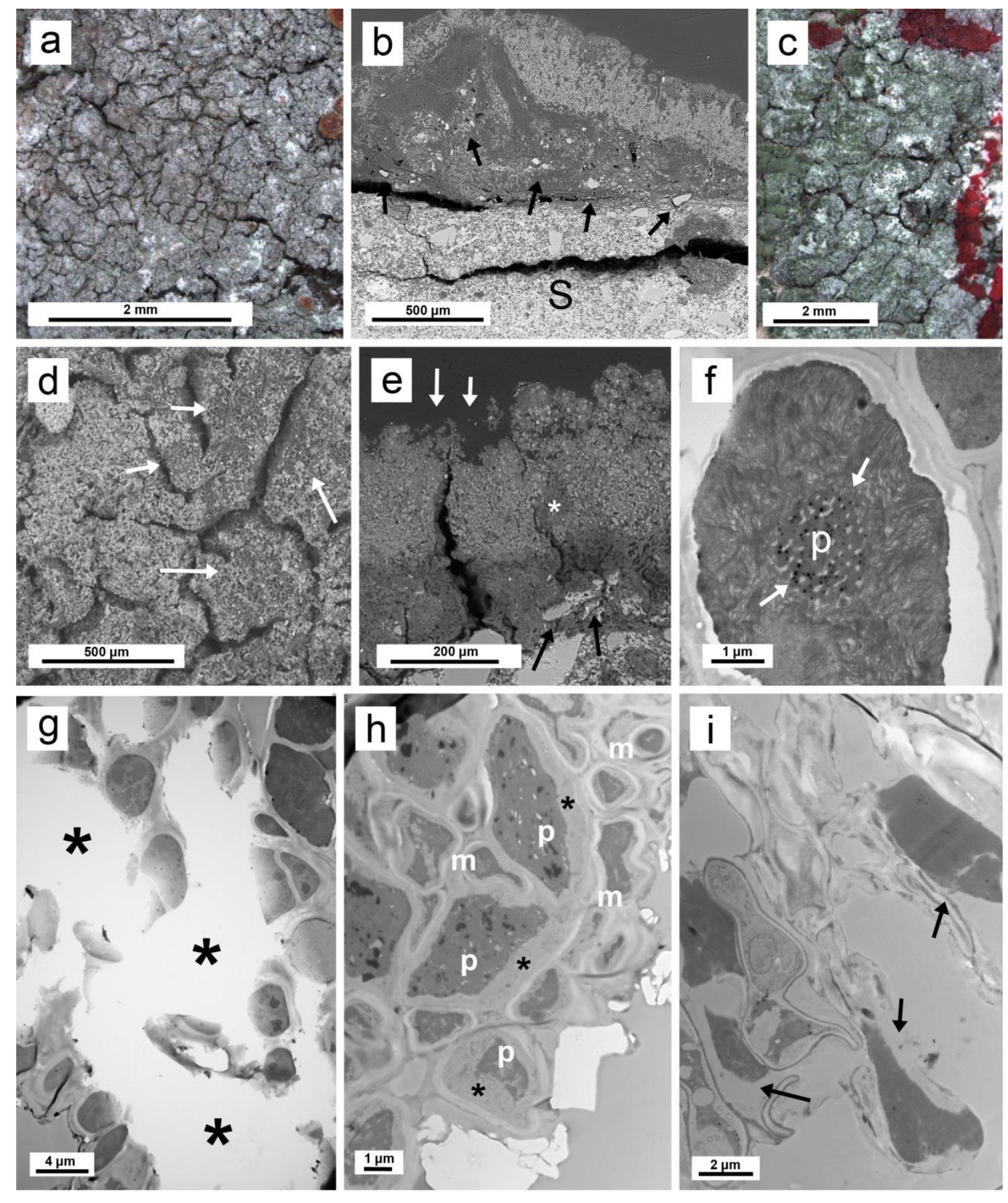

Figure 4 


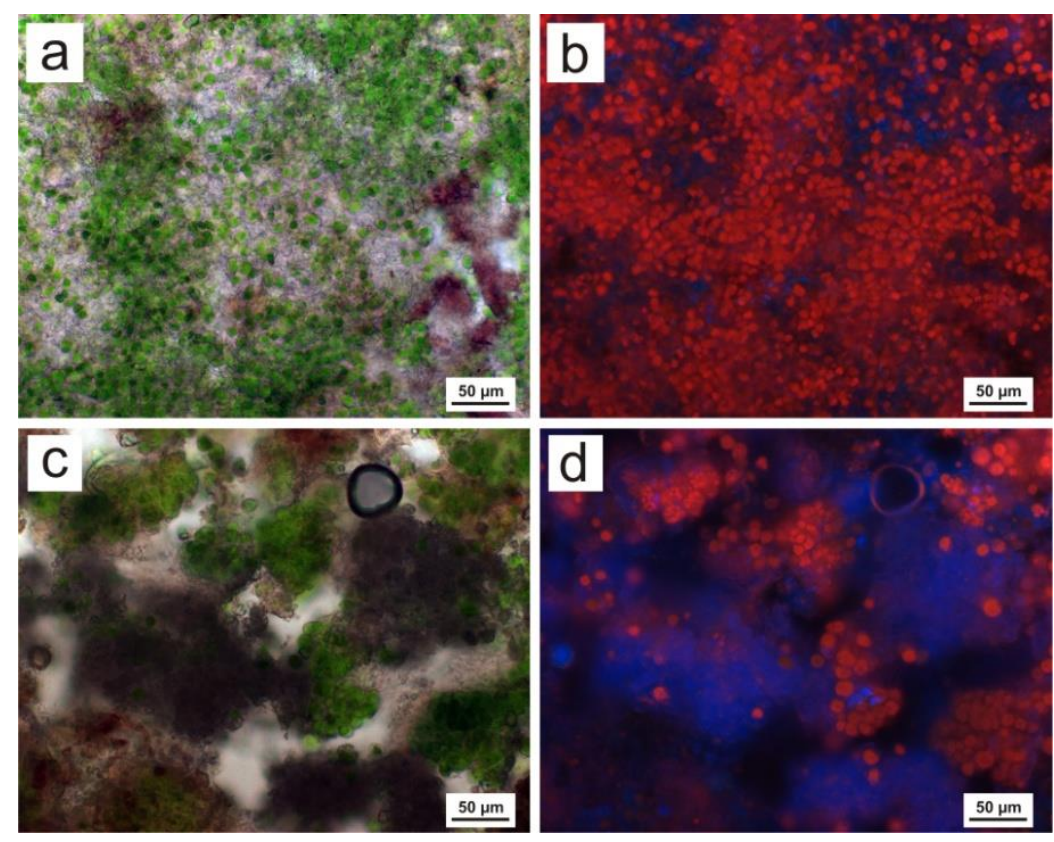

Figure 5 
Table 1. Resulting data from ceramic roofing tiles characterization.

\begin{tabular}{|c|c|c|c|c|c|c|c|c|c|}
\hline \multirow[t]{2}{*}{ Sample } & \multirow[t]{2}{*}{ Matrix } & \multirow[t]{2}{*}{ Birefringence } & \multirow[t]{2}{*}{ Type of clay } & \multirow[t]{2}{*}{ Porosity } & \multicolumn{3}{|c|}{ Inclusions } & \multirow{2}{*}{$\begin{array}{l}\text { Neoformed } \\
\text { phases (XRD) }\end{array}$} & \multirow{2}{*}{$\begin{array}{l}\text { Firing } \\
\text { temperature } \\
\text { (estimated) }\end{array}$} \\
\hline & & & & & Type & Size & Morphology & & \\
\hline Tile 1 & $\begin{array}{l}\text { Reddish, } \\
\text { homogeneous }\end{array}$ & $\begin{array}{l}\text { Low } \\
\text { (initial vitrification) }\end{array}$ & $\begin{array}{l}\text { Illitic-smectitic } \\
\text { (non } \\
\text { calcareous) }\end{array}$ & Medium & $\begin{array}{l}\text { Quartz, feldspars, } \\
\text { opaque iron } \\
\text { oxides }\end{array}$ & $\begin{array}{l}500 \mu \mathrm{m} \text { on } \\
\text { average (some } \\
\text { up to } 2 \mathrm{~mm} \text { ) }\end{array}$ & $\begin{array}{l}\text { Rounded to } \\
\text { sub-rounded }\end{array}$ & $\begin{array}{l}\text { Diopside, } \\
\text { gehlenite, } \\
\text { hematite }\end{array}$ & $850-900^{\circ} \mathrm{C}$ \\
\hline Tile 2 & $\begin{array}{l}\text { Intense } \\
\text { reddish, } \\
\text { homogeneous }\end{array}$ & $\begin{array}{l}\text { High } \\
\text { (no vitrification) }\end{array}$ & $\begin{array}{l}\text { Illitic } \\
\text { (non } \\
\text { calcareous) }\end{array}$ & Medium & $\begin{array}{l}\text { Quartz, feldspars, } \\
\text { mica }\end{array}$ & $\begin{array}{l}500 \mu \mathrm{m} \text { on } \\
\text { average (some } \\
\text { up to } 2 \mathrm{~mm})\end{array}$ & $\begin{array}{l}\text { Rounded to } \\
\text { sub-angular }\end{array}$ & Hematite & $750-800^{\circ} \mathrm{C}$ \\
\hline Tile 3 & $\begin{array}{l}\text { Ochre, poor } \\
\text { homogenized }\end{array}$ & $\begin{array}{l}\text { Very low } \\
\text { (advanced } \\
\text { vitrification) }\end{array}$ & $\begin{array}{l}\text { Kaolinitic } \\
\text { (calcareous) }\end{array}$ & Medium-high & $\begin{array}{l}\text { Quartz, opaque } \\
\text { iron oxides }\end{array}$ & $\begin{array}{l}200 \mu \mathrm{m} \text { on } \\
\text { average (one } \\
\text { more than } 1 \mathrm{~cm} \text { ) }\end{array}$ & Rounded & $\begin{array}{l}\text { Anorthite, } \\
\text { diopside, } \\
\text { gehlenite, } \\
\text { mullite }\end{array}$ & $950-1000^{\circ} \mathrm{C}$ \\
\hline
\end{tabular}

Table 2. Colorimetric coordinates of the reference (cut edge), non-treated and laser treated areas of the ceramic roofing tiles.

\begin{tabular}{|l|l|r|r|r|r|r|r|r|}
\hline Sample & Area & $L^{*}$ & $a^{*}$ & $b^{*}$ & $\Delta L^{*}$ & $\Delta a^{*}$ & $\Delta b^{*}$ & $\Delta E^{*}$ \\
\hline Tile 1 & $\begin{array}{l}\text { Reference } \\
\text { (cut edge) }\end{array}$ & 58.3 & 19.6 & 21.4 & \multicolumn{4}{|c|}{} \\
\cline { 2 - 9 } & Non-treated & 31.0 & 4.1 & 8.1 & -27.3 & -15.5 & -13.3 & 34.1 \\
\cline { 2 - 10 } & Laser treated & 50.7 & 7.3 & 12.6 & -7.6 & -12.3 & -8.8 & 16.9 \\
\hline \multirow{7}{*}{ Tile 2 } & $\begin{array}{l}\text { Reference } \\
\text { (cut edge) }\end{array}$ & 50.8 & 24.2 & 22.3 & \multicolumn{4}{|c|}{} \\
\cline { 2 - 10 } & Non-treated & 40.5 & 12.1 & 22.0 & -10.3 & -12.1 & -0.3 & 15.9 \\
\cline { 2 - 10 } & Laser treated & 55.5 & 11.9 & 14.4 & 4.7 & -12.3 & -7.9 & 15.3 \\
\hline Tile 3 & $\begin{array}{l}\text { Reference } \\
\text { (cut edge) }\end{array}$ & 75.1 & 7.9 & 20.0 & \multicolumn{4}{|c|}{} \\
\cline { 2 - 10 } & Non-treated & 52.7 & -0.4 & 9.6 & -22.4 & -8.3 & -10.4 & 26.1 \\
\cline { 2 - 9 } & Laser treated & 60.3 & 4.9 & 14.3 & -14.8 & -3.0 & -5.7 & 16.1 \\
\hline
\end{tabular}


Table S1 (Supplementary material). Chemical composition of ceramic roofing tiles obtained by XRF.

\begin{tabular}{|c|c|c|c|c|c|c|c|c|c|c|c|c|c|c|}
\hline \multirow[b]{2}{*}{ Sample } & \multicolumn{14}{|c|}{ Oxides (wt \%) } \\
\hline & $\mathrm{Na}_{2} \mathrm{O}$ & $\mathrm{MgO}$ & $\mathrm{Al}_{2} \mathrm{O}_{3}$ & $\mathrm{SiO}_{2}$ & $\mathrm{P}_{2} \mathrm{O}_{5}$ & $\mathrm{SO}_{3}$ & $\mathrm{~K}_{2} \mathrm{O}$ & $\mathrm{CaO}$ & $\mathrm{TiO}_{2}$ & $\mathrm{MnO}$ & $\mathrm{Fe}_{2} \mathrm{O}_{3}$ & $\mathrm{Rb}_{2} \mathrm{O}$ & $\mathrm{SrO}$ & $\mathrm{BaO}$ \\
\hline Tile 1 & 1.29 & 3.32 & 20.06 & 59.59 & 0.21 & 0.07 & 4.19 & 4.50 & 0.89 & 0.04 & 5.74 & 0.02 & 0.01 & 0.07 \\
\hline Tile 2 & 1.26 & 2.43 & 23.80 & 56.10 & 0.28 & 0.11 & 4.04 & 1.24 & 1.13 & 0.11 & 9.40 & 0.03 & 0.02 & 0.08 \\
\hline Tile 3 & -- & 14.10 & 12.70 & 41.10 & 0.16 & 0.30 & 2.26 & 23.40 & 0.67 & 0.06 & 5.12 & 0.02 & 0.16 & -- \\
\hline
\end{tabular}

--- not detected

Table S2 (Supplementary material). Raman wavenumbers (in $\mathrm{cm}^{-1}$ ) and vibrational band assignment for roofing tile sample 3 .

\begin{tabular}{|c|c|c|c|}
\hline $\begin{array}{l}\text { Bare ceramic } \\
\text { substrate }\end{array}$ & $\begin{array}{l}\text { Before irradiation } \\
\text { (non-treated) }\end{array}$ & $\begin{array}{l}\text { After irradiation } \\
\text { (treated) }\end{array}$ & Vibrational assignment \\
\hline & 1669 & 1674 & $v\left(\mathrm{CO}_{2}\right)$ whewellite \\
\hline & 1524 & & $v(\mathrm{C}=\mathrm{C})$ carotene \\
\hline & 1490 & 1490 & $v(\mathrm{CO})$ whewellite \\
\hline & 1464 & 1464 & $v(\mathrm{CO})$ whewellite \\
\hline & 1188 & & Ring stretch, C-C chelate, parietin \\
\hline & 1160 & & $\begin{array}{l}v(\mathrm{CC}) \text { stretching, carotene } \\
\delta(\mathrm{OH}) \text { phenyl, free, in plane, parietin }\end{array}$ \\
\hline \multirow[t]{4}{*}{1086} & 1082 & 1080 & $\begin{array}{l}\mathrm{SiO}_{2} \text { stretching, } \alpha \text {-quartz } \\
v_{1} \text {-symmetric } \mathrm{CO}_{3} \text { stretching }\end{array}$ \\
\hline & 995 & & $v(\mathrm{CC})$ ring breathing, carotene \\
\hline & 899 & 895 & $v(\mathrm{CC})$ whewellite \\
\hline & 504 & 504 & $\delta\left(\mathrm{CO}_{2}\right)$ whewellite \\
\hline 465 & & 465 & $\mathrm{SiO}_{2}$ bending, $\alpha$-quartz \\
\hline 347 & & 340 & $\mathrm{SiO}_{2}$ bending, $\alpha$-quartz \\
\hline 297 & & & Lattice translational modes $\left(\mathrm{Ca}, \mathrm{CO}_{3}\right)$ \\
\hline 207 & & 207 & $\mathrm{SiO}_{2}$ twisting, $\alpha$-quartz \\
\hline 145 & & 145 & $\mathrm{SiO}_{2}$ twisting, $\alpha$-quartz \\
\hline
\end{tabular}

